\title{
Erratum to: Social Information Processing in Preschool Children Diagnosed with Autism Spectrum Disorder
}

\author{
Yair Ziv • Bat Sheva Hadad • Yasmine Khateeb • \\ Ruth Terkel-Dawer
}

Published online: 29 November 2013

(C) Springer Science+Business Media New York 2013

\section{Erratum to: J Autism Dev Disord}

DOI 10.1007/s10803-013-1935-3

The author of the article has overlooked to include one coauthor's name, Ruth Terkel-Dawer, in the original publication of the article. The complete author's group and their affiliations are presented in this erratum.

The online version of the original article can be found under doi:10.1007/s10803-013-1935-3.

Y. Ziv $(\bowtie) \cdot$ Y. Khateeb

Department of Counseling and Human Development, University of Haifa, 31905 Haifa, Israel

e-mail: yziv@edu.haifa.ac.il

B. S. Hadad

Department of Special Education, University of Haifa,

Haifa, Israel

Y. Khateeb · R. Terkel-Dawer

Institute of Pediatric Neurology and Child Development,

Clalit Health Services, Haifa, Israel 